\title{
Exploring Extended Nomological Network of Antecedents, Moderators, and Consequences of Brand Love
}

\author{
Muhammad Asif Khan* \\ Department of Marketing, College of Business, King Abdulaziz University, P.O. Box 344, Rabigh-21911, Saudi \\ Arabia \\ * E-mail of the corresponding author: mabkhan@,kau.edu.sa
}

\begin{abstract}
This study explores an emerging marketing construct 'brand love' with its seven dimensions proposed by Bagozzi et al. (2016). It has a unique theoretical contribution in literature by exploring antecedents (brand satisfaction and brand equity) and consequences (brand loyalty, positive word-of-mouth (WOM), willingness to pay price premium, and resistance to negative information) of brand love for smartphone brands in Pakistani context. Extending the previous research, this study explored the underlying mechanism in the nomological network of brand love, through building brand love as a mediator and consumer expertise as moderator on the relationship with antecedents and consequences of brand love. The data were collected from 402 respondents using conveniencesampling technique and full model was analyzed using PLS Structure Equation Modeling. The empirical findings showed that brand satisfaction was a significant predictor of brand love, and through mediation mechanism of brand love, it influences brand loyalty, positive WOM, willingness to pay price premium and resistant to negative information. The empirical significance of moderated effect of consumer expertise with smartphone brand provided new insights into the boundary conditions of consumer judgment.
\end{abstract}

Keywords: Brand Love, Brand satisfaction, loyalty, WOM, Premium Prices, Resistance

DOI: $10.7176 / \mathrm{JMCR} / 61-05$

Publication date:October $31^{\text {st }} 2019$

\section{Introduction}

Firms wish to retain existing customers with an urge to attract more through their unique products and services to maximize profit margins and market shares. The challenge is to convert customer satisfaction into a long term relationship and take it as a competitive advantage over competitors. Enormous research has been conducted in this regard and through these findings researchers helped firms to maximize their profits by satisfying customers and enhancing their brand image (Keller, 1993). However, in the current turbulent environment, it is difficult to tie up customers through such notions only because customers have a variety of similar products and services and they can easily switch from one brand to another (Batra et al., 2012). Thus, the challenge for managers is to retain customers forever or at least for a longer period of time. To deal with it, academics and practitioners found a new construct "brand love" which seems to be more meaningful and reliable in retaining customers for longer time (Carroll and Ahuvia, 2006). It is expected that after developing brand love, customers will develop stronger intention to repurchase their be-loved brands (Batra et al., 2012).

In fact it was Rubin (1970) who worked on human-love like feelings towards brands and conceptualized this construct for the first time. Love inspires and motivates human beings (Argyle and Henderson, 1984) and this makes it a central concern for marketing manager (Carroll and Ahuvia, 2006). Researchers have studied this construct in various settings (Batra et al., 2012; Carroll and Ahuvia, 2006; Hendrick and Hendrick, 2006; Sternberg, 1986). Particularly, the work has been revolving around constructs such as self-brand connection (Escalas, 1997), brand image (Keller, 1993), WOM (Westbrook, 1987), customer satisfaction (Fournier, 1998), brand loyalty (Oliver, 1999), and brand attachment (Ahuvia, 2005; Park et al., 2010).

Although, the construct has been developed and empirically tested in western countries decades ago, still a little effort has been made to understand Asian consumers' perspective towards brand love despite being a major chunk of the world population (Eckhardt and Dholakia, 2013). One of the purposes of this study is to contribute in filling this gap in literature by exploring brand love in South Asian context (Pakistan).

Globalization has increased difficulties of marketing managers in attracting and retaining new customers. 
Increased competition, availability of substitutes, and intense price wars are the key challenges of current era. Managers are aware of the fact that traditional approaches may not help them in achieving their targets. Some of the examples from Asian markets are Nokia (mobile brand), ICI Paints (home paint brand) and Dawlance (appliance brand) who lost their market shares in recent time. In the struggle to revive their market shares, these firms are bringing innovative products, better pricing strategies, and providing better services to compete in the market. Along with technology and innovation, the firms want to create an emotional bond with their customers that may increase their repurchase intentions for their brands (Batra et al., 2012).

Building on the previous research and identifying certain gaps in literature, this study contributes to the brand love literature in the following domains. First, it extends the generalizability of nomological network of brand love construct from Western to South Asian context by exploring important antecedents and consequences of brand love. Second, it explores the mechanism underlying the relationship of brand love with its antecedents and consequences through building brand love as mediator and customer expertise with brand as an important moderator in the model. Third, Batra et al. (2012) studied brand love concept extensively and contributed in marketing literature. However, their work has been cited in around 700 published papers to date, none of them has used their proposed scale of brand love. This study provides the psychometric evidence regarding the measurement artifacts of Bagozzi et al.'s (2016) brand love construct in terms of its reliability and validity in the Asian context.

\section{Literature review}

\subsection{Brand love}

Brand love has been the focus of researchers since the last decade (Roy et al., 2013). The concept has been derived from the notion of interpersonal love in psychology (Carroll and Ahuvia, 2006; Shimp and Madden, 1988) and has been applied on consumer behavior. On the other hand, Albert et al. (2008) and Batra et al. (2012) took another approach to explore it through in-depth qualitative interviews about things that people love and compare this noninterpersonal love for brands with interpersonal love (Rauschnabel and Ahuvia, 2014). Caroll and Ahuvia (2006) presented brand love as an individual's emotional and passionate feeling for a trade name that might lead to commitment (repurchase) over a longer time. Whereas, according to Fournier (1998), love is a core element of consumer-brand relationship.

In the last decade, several empirical studies have been conducted on brand love (Albert et al., 2008; Bagozzi et al., 2016; Batra et al., 2012; Carroll and Ahuvia, 2006) with an evolution of measuring scales. Brand love has been explored in literature from one-dimension (Carroll and Ahuvia, 2006) to an 11 dimensional construct (Albert et al., 2008) with differing conceptualizations. Carroll and Ahuvia (2006) proposed that brand love is a single and specific emotional reaction; whereas, Batra et al. (2012) following Fournier (1998) proposed that brand love is not due to specific emotion but because of relationship with number of attributes or features of brand called prototypes.

\subsection{Brand Love Prototype Model}

Apart from theoretical disagreement researchers are also not convinced on one measurement method of brand love and different scales have been used to measure it so far. It is still not clear which one of the available scales has better measurement and predictability features (Ahuvia et al., 2013; Albert et al., 2008; Bagozzi et al., 2016; Batra et al., 2012; Carroll and Ahuvia, 2006; Rossiter, 2012). A recent literary debate on classical style verses prototype definition (Ahuvia et al., 2013) of brand love is a point of concern on the choice of how to measure brand love. On a series of studies Batra et al. (2012) found brand love as a type of consumer-brand relationship. In contrast, Rossiter (2012) defined it as the simultaneous experience based on affection (passion) and separation anxiety. In recent times, a great effort has been put by Bagozzi et al. (2016) in developing and validating brand love scale based on the work of Batra et al. (2012). They provided three scales based on 26-items, 13-items, and 6-items versions of brand love that predict the outcome variables of brand love such as loyalty, WOM, and Resistance with an $\mathrm{R}^{2}$ of .90. The application and validation of these scales in different contexts will confirm their contribution in literature and this study may contribute to the measurement of brand love. Moving on, we will discuss the conceptual framework of the study in terms of its key antecedents, moderator and consequences of brand love.

\section{Antecedents of Brand Love}

\subsection{Brand Satisfaction}

According to Fournier and Mick (1999), satisfaction is a post-purchase attitude like judgment based on a series of consumer-product interactions. Similarly, Thomson et al. (2005) claimed that after multiple interactions with a brand, the post-consumption satisfaction may lead to an emotional attachment with the brand. Carroll and Ahuvia 
(2006) argued that satisfied consumers might involve in this relationship. The cumulative satisfaction over a period leads to an emotional bonding between consumer and brand. Brand love and satisfaction are two different (Carroll and Ahuvia, 2006) but interlinked constructs (Fournier and Mick, 1999). In their study of love for wine brands, Loureiro and Kaufmann (2012) found that satisfaction is an antecedent of brand love. Hence, we took satisfaction as a strong predictor of brand love in our study (Figure 1).

\section{$H_{1}$ : Brand Satisfaction positively influences consumer's love towards smartphone brands.}

\subsection{Brand Equity}

Brand is a name, a symbol, a figure or a combination of these elements with an intention to be identified as unique and differentiated from competitors (AMA, 1960). A brand is composed of tangible and intangible elements. Generally, a strong brand is developed based on intangible elements or attributes. These attributes take a place in the minds of consumers and cannot be copied easily or transferred to other forms (Keller, 2003). Brand equity is the term used to refer intangible assets of a brand that increase consumer's perceived benefits and value of a product or service far beyond the tangible offer itself (Keller, 2003). From the consumer's point of view, brand equity is a set of resources or deficiencies that aggregates or subtracts the value of a product or a service (Aaker, 1995). Perceived quality is one of the dimension of customer-based brand equity. It refers to as the quality or superiority of an offering that influences consumer's purchase decision (Ha et al., 2010). Brand association is also a dimension of brand equity. Aaker (1991) refers to it as anything that links to the memory of a brand which helps retrieval of information related to the brand and provide a reason to purchase it over other brands. Brand equity has been the focus in marketing literature to identify its antecedents and consequences. Hence, we propose our hypothesis as follows:

\section{$\mathrm{H}_{2}$ : Brand equity positively influences consumer's love towards smartphone brands.}

\section{Consequences of Brand Love}

\subsection{Brand Loyalty}

Oliver (1999) described loyalty a deep commitment to repurchase a brand and consumers continue to purchase the same brand. Brand loyalty is a complex phenomenon and multiple types have been explored in the past, such as attitudinal and behavioral loyalty. Attitudinal loyalty is the measure of positive attitude towards the brand, whereas behavioral loyalty is the measure of repeated purchase (Tuominen, 1999). Roy et al. (2013) proposed that satisfied

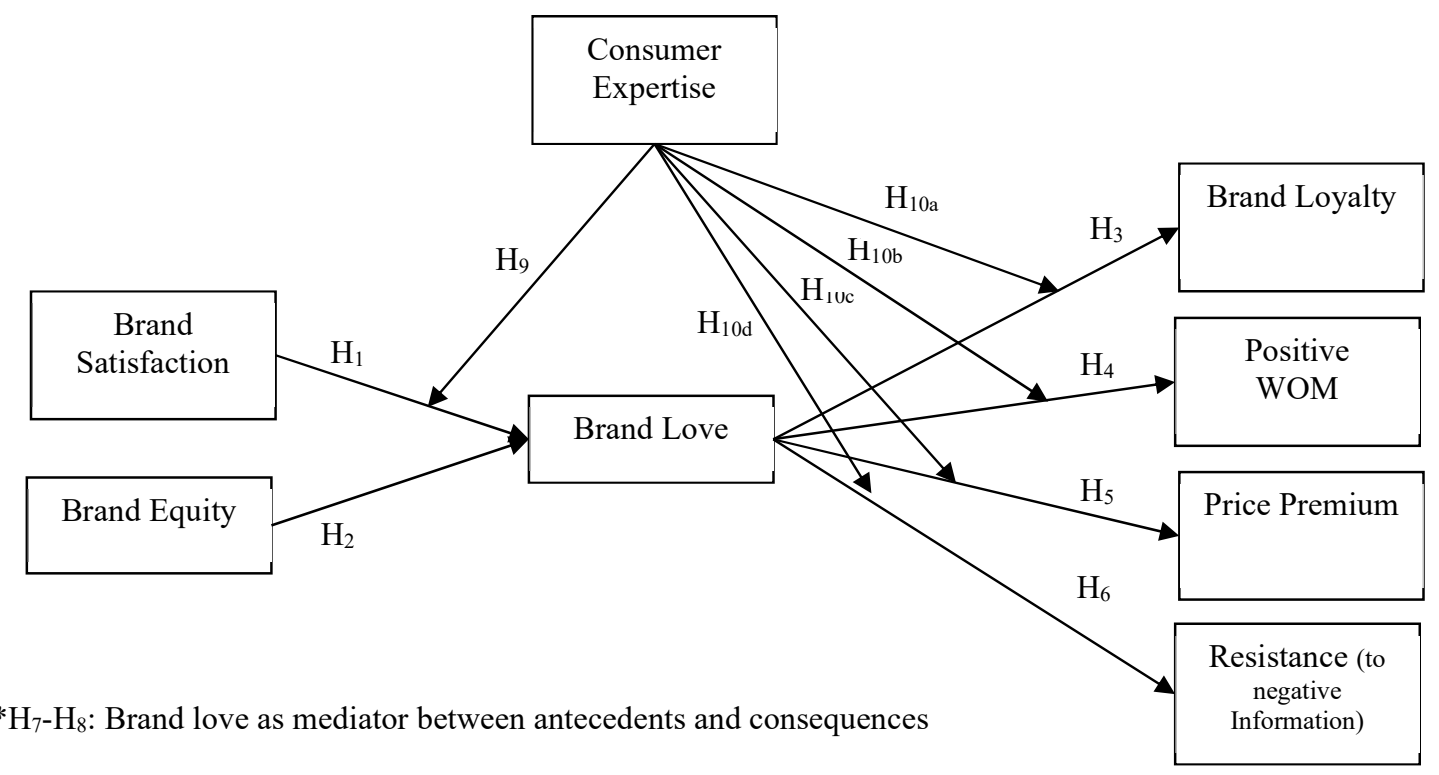

Figure 1: Conceptual Model

customers having a strong love bond with brand show much more stronger brand loyalty as compared to those without this love-based bonding with brand. When consumer starts loving a brand, he/she develops an emotional and passionate bond with the brand over a period of time that leads to repurchase over competitors brands. Previous 
researches have provided empirical support for the relationship between brand love and brand loyalty (Carroll and Ahuvia, 2006). Hence, we propose:

$H_{3}$ : Brand love with smartphones positively influences brand loyalty.

\subsection{Positive Word-of-Mouth}

Consumer-brand relationship based on emotional and passionate attachment may lead a consumer to say positive things about the brand in their social networks. WOM is the degree to which the consumer say positive things about a brand to others (Westbrook, 1987). Bergkvist and Bech-Larsen (2010) included positive WOM in their study as a component of active engagement. They concluded that consumers' love based relationship with the brands actively engages them to visit brand websites and share their opinions about brands in their social networks online or offline. Consumers are willing to invest their time and energy in spreading positive things about their loved brands. Sheth (1971) and Day (1971) confirmed that WOM is more important and nine times as effective as advertising in securing a positive attitude to try a product. Several studies showed positive relationship between brand love and positive WOM for brands (Carroll and Ahuvia, 2006; Roy et al., 2013). Thus, we hypothesize that high brand love leads to more positive WOM. Hence, we propose:

\section{$H_{4}$ : Brand love with smartphones positively influences positive WOM.}

\subsection{Willingness to Pay Price Premium}

Price premium is the amount that customers are willing to pay higher for a brand as compared to other competitors' brands in the same category (Aaker, 1996). Price premium has been considered as the most useful indicator of strong brand equity (Aaker, 1996; Sethuraman, 2001) and powerful predictor of market shares (Ailawadi et al., 2003). Doyle (2001) argued that price premium helps in enhancing shareholder value because it does not need any direct investment to charge high price. Although price premium has an important place in branding theory, yet it requires further empirical support about which specific elements of brand image it should be built upon (Anselmsson et al., 2014). Customers will pay higher premium if they perceive quality differential between their loved brand and other brands. According to Thomson et al. (2005) if a customer is emotionally attached with a brand then it is quite possible that $\mathrm{s} / \mathrm{he}$ will be ready to pay a price premium for it. Hence, we propose:

\section{$H_{5}$ : Brand love with smartphones positively influences willingness to pay price premium.}

\subsection{Consumer Resistance to Negative Information}

Consumer's resistance to negative information about the brand/firm has been explored in the past literature (Batra et al., 2012; Marin et al., 2009). Previous studies concluded that consumers build stronger relationship with those firms that care their best interests and is engaged in corporate social responsibility (CSR). Consumers care about how they are treated and what they get in terms of products/brands. Customers were found to be more loyal, had positive firm evaluation, and showed higher identification with the firms that practice greater CSR activities (Marin et al., 2009). Bhattacharya and Sen (2003) concluded that consumers are more likely to forgive company's mistakes if they feel connected with them. It is a relationship based on the norm of reciprocity, i.e. the more a company cares about its consumers, the more they will be inclined to resist against negative information about that company/brand. Ahearne et al. (2005) found that loved brands become part of consumers' identity and in that sense they tend to resist negative information about themselves. Hence, we propose:

$H_{6}$ : Brand love with smartphones positively influences consumer resistance to negative information about the brand.

\section{Brand love as a Mediator}

According to Hayes (2013), one can establish the causal relationship between X and Y but it is always more interesting to know the underlying mechanism through which the causal effect operates. The mechanism is studied under mediation analysis (Baron and Kenny, 1986; Hayes, 2013; Zhao et al., 2010) with the existence of an indirect effect of X (independent variable) on Y (dependent variable) through mediator(s) (M) variable(s). In our study, in addition to the direct effects of antecedents to brand love and further brand love to outcomes variables, we propose the mediating effect of brand love between antecedents (brand satisfaction and brand equity) and outcome variables (brand loyalty, positive WOM, willingness to pay price premium and resistance to negative information) as follows.

$H_{7}$ : Brand love mediates the relationship between brand satisfaction and (a) brand loyalty, (b) positive WOM, (c) willingness to pay price premium, and (d) resistance to negative information

$H_{8}$ : Brand love mediates the relationship between brand equity and (a) brand loyalty, (b) positive WOM, (c) 
willingness to pay price premium, and (d) resistance to negative information

\section{Customer Expertise with Brand (CEB) as a Moderator}

Studies conceptualized consumer's experience with a product/brand as feelings, cognitions, sensations, and behavioral responses generated by a brand or product stimuli. Stimuli are the combination of brand identity, packaging, design, communications, and specific environment that fascinate the consumer about a brand/product (Brakus et al., 2009). Consumer knowledge is deliberately not taken into discussion because it has been studied in various cultures (Guo and Meng, 2008) and found that level of consumer knowledge is not a strong predictor of consumer's behavior and activities. According to Mason and Bequette (1998), the consumers having higher level of expertise with brands can access new information about brand from prior knowledge. A Consumer's previous expertise with a brand forces him to trust the brand quickly, show less ambiguity about the brand, and purchase brand more easily as compared to a consumer without prior experience with the brand. It is assumed that a good and favorable brand experience over a period of time will affect consumer decision making (Carroll and Ahuvia, 2006).

Consumer expertise is conceptualized as who is comfortable in purchasing and using smartphones brands. Based on the above-mentioned discussion, consumer expertise with smartphones has been proposed as a moderator in this study. This means that antecedents of brand love (brand satisfaction and brand equity) will result in higher levels of brand love for those customers with higher levels of expertise with the smartphone brands than those with lower levels of expertise. That is to say, consumer expertise with smartphone brands will serve as a boundary condition for the effects of antecedents and brand love as well as brand love and its proposed consequences. We, therefore, propose following moderating effects of consumer expertise on the relationships with antecedents and outcomes of brand love:

$H_{9}:$ Higher the level of expertise with a smartphone brand, stronger will be the relation between brand satisfaction and brand love.

$H_{10}$ : Higher the level of expertise with a smartphone brand, stronger will be the relation between brand love and (a) brand loyalty, (b) positive WOM, (c) willingness to pay price premium, and (d) resistance to negative information

\section{Methodology}

7.1 Measures.

We adapted the items from scales that have already been used in many studies. Brand love was measured with 6 dimensions i.e. (1) Self-Brand Integration (SBI), (2) Passion-Driven Behaviors (PDB), (3) Positive Emotional Connections (PEC), (4) Long-Term Relationship (LTR), (5) Anticipated Separation Distress (ASD), and (6) Attitude Valence (AV) based on Batra et al. (2012). Bagozzi et al. (2016) and Rauschnabel and Ahuvia (2014) found that seventh dimension "Attitude Strength 2" was not significant with remaining constructs of brand love. Since the respondents did not consider it a part of brand love construct in their study so, we did not include it in our study. Bagozzi et al. (2016) used brand love as a single factor in their study by computing the averages of items. Alternatively, we used factor scores of first and second order constructs to ensure more representation of variance measured in the brand love construct (Hair et al., 2009; Tabachnick and Fidell, 2013). The questions were rephrased so that respondents could focus on their favorite smartphone brands. e.g. "concerning your favorite smartphone brand, to which extent do you agree with the following statements". Respondents rated all items measuring brand love on a 7-point scale ranging from 1 (Not at all) to 7 (Very much) as per the recommendation of Batra et al. (2012) and Bagozzi et al. (2016).

Brand satisfaction was measured with four items based on Brakus et al. (2009) and Batra et al. (2012). Whereas, brand equity was measured with four items including brand awareness and brand associations based on Keller (1993). Brand loyalty was measured with 9 items adapted from Chaudhuri and Holbrook (2001) and Batra et al. (2012). Positive-WOM was assessed with three items adapted from Zeithaml et al. (1996). Willingness to pay price premium was measured with three items adapted from Anselmsson et al. (2014). Resistance to negative information about their favorite brand was measured with four items adapted from Eisingerich et al. (2011) and Customer expertise with brand was measured with three items adapted from Eisingerich et al. (2011) and Loureiro and Kaufmann (2012). All items were measured on 7-points Likert scale from (1) strongly disagree to (7) strongly agree. Finally, consumers' gender, income, and qualification were included as control variables. 


\subsection{Sample Statistics.}

A sample of 402 valid respondents was collected to analyze the data. Males were $278(69.2 \%)$ and females 124 $(30.8 \%)$. In qualification, $381(94.8 \%)$ had graduate level education or more. $325(80.8 \%)$ responses were from "less than or equal to 30 years" that represents youth of the population and makes it more representative sample of smartphone users. Moreover, 204 (50.7\%) responses came from students, which made it a good mixture of students and professionals. Descriptive statistics of the main variables are provided in the Table 1.

Table 1: Mean, SD and Correlations among variables

\begin{tabular}{|c|c|c|c|c|c|c|c|c|}
\hline & M (SD) & 1 & 2 & 3 & 4 & 5 & 6 & 7 \\
\hline 1. Br_Equity & $4.87(1.40)$ & & & & & & & \\
\hline 2. Br_Satisfaction & $5.20(1.26)$ & $.090 \dagger$ & & & & & & \\
\hline 3. Br_Love $\mathrm{a}^{\mathrm{a}}$ & $0.83(0.56)$ & .049 & $.665 * * *$ & & & & & \\
\hline 4. CEWB & $5.08(1.24)$ & $.097 *$ & $.602 * * *$ & $.647 * * *$ & & & & \\
\hline 5. Br-Loyalty & $5.14(1.23)$ & $.510 * * *$ & $.241 * * *$ & $.179 * * *$ & $.193 * * *$ & & & \\
\hline 6. Positive WOM & $5.26(1.26)$ & $.492 * * *$ & $.190 * * *$ & $.180 * * *$ & $.166 * * *$ & $.686 * * *$ & & \\
\hline 7. Price Premium & $5.22(1.18)$ & $.424 * * *$ & $.222 * * *$ & $.164 * * *$ & $.209 * * *$ & $.759 * * *$ & $.581 * * *$ & \\
\hline 8. Resist & $5.40(1.26)$ & $.516^{* * *}$ & $.131^{* *}$ & $.149 * *$ & $.125 * *$ & $.464 * * *$ & $.453 * * *$ & $.346^{* * *}$ \\
\hline
\end{tabular}

${ }^{a}$ Based on factor score loadings;

Where: $* * * p<.001 ; * * p<.01 ; * p<.05$; whereas, $† p<.10$

7.3 Measurement Validation.

The measurement model was validated, using WarpPLS statistical software version 6.0, with the average path coefficient, average variance inflation factor, and average full collinearity (Kock, 2015). Model's explanatory power is measured with Tenenhaus GoF. Wetzels et al. (2009) proposed the criteria that explanatory power is small if $\mathrm{GoF} \geq .10$, medium if $\mathrm{GoF} \geq .25$, and large if $\mathrm{GoF} \geq .36$. In our model $\mathrm{GoF}=.496$ which shows large explanatory power of the model. All the quality indices met recommended criteria, suggesting that our model has a good fit (Table 2).

Table 2: Model Fit and Quality Indices

\begin{tabular}{|c|c|c|}
\hline Model Fit and Quality Indices & Status & Fit Criteria \\
\hline Average path coefficient $(\mathrm{APC})=0.154, \mathrm{P}=0.001$ & Accepted & $\mathrm{p}<.05$ \\
\hline Average R-squared $(\mathrm{ARS})=0.328, \mathrm{P}<0.001$ & Accepted & $\mathrm{p}<.05$ \\
\hline Average adjusted R-squared (AARS) $=0.318, \mathrm{P}<0.001$ & Accepted & $\mathrm{p}=.14$ \\
\hline Average block VIF $(\mathrm{AVIF})=1.188$ & Good Fit & Acceptable if $<=5$, Ideally $<=3.3$ \\
\hline Average full collinearity VIF (AFVIF) $=1.944$ & Good Fit & Acceptable if $<=5$, Ideally $<=3.3$ \\
\hline Tenenhaus GoF $(\mathrm{GoF})=0.496$ & Large & small $>=0.1$, medium $>=0.25$, large $>=0.36$ \\
\hline Sympson's paradox ratio $(\mathrm{SPR})=0.857$ & Good Fit & Acceptable if $>=0.7$, Ideally $=1$ \\
\hline R-squared contribution ratio $(\mathrm{RSCR})=0.964$ & Good Fit & Acceptable if $>=0.9$, Ideally $=1$ \\
\hline Statistical suppression ratio $(\mathrm{SSR})=0.893$ & Good Fit & Acceptable if $>=0.7$ \\
\hline $\begin{array}{l}\text { Nonlinear bivariate causality direction ratio } \\
(\mathrm{NLBCDR})=0.839\end{array}$ & Accepted & Acceptable if $>=0.7$ \\
\hline
\end{tabular}


The factor structure worked out satisfactorily (Table 3). Composite reliabilities and Cronbach's alpha coefficients are all higher than .80; average variance extracted for all constructs is higher than the minimal cut-off of .50. Factor loadings are good, higher than the commonly used cut-off of .70. Thus, our measures demonstrate adequate convergent validity and reliability.

Table 3: Measurement Validity

\begin{tabular}{lcccc}
\hline Constructs & CR & $\begin{array}{c}\text { Cronbach's } \\
\text { Alpha }\end{array}$ & AVE & VIF \\
\hline Brand Equity & .906 & .857 & .709 & 1.643 \\
Brand Satisfaction & .885 & .826 & .658 & 2.398 \\
Brand Love & .934 & .914 & .704 & 2.234 \\
CEWB & .874 & .783 & .699 & 2.085 \\
Brand Loyalty & .936 & .923 & .620 & 3.242 \\
Positive WOM & .912 & .855 & .776 & 2.106 \\
Price Premium & .894 & .822 & .738 & 2.465 \\
Resistance to Negative Information & .909 & .850 & .769 & 1.544 \\
\hline
\end{tabular}

Notes: $\mathrm{CR}=$ composite reliability, $\mathrm{AVE}=$ average variance extracted, $\mathrm{VIF}=$ Full Collinearity Variance Inflation Factor

We also assessed discriminant validity using Fornell and Larcker's (1981) procedure. Average variance extracted for each construct was much higher than all the squared correlation coefficients between the pairs of latent variables. Hence, discriminant validity was established (Table 4).

Table 4: Discriminant validity among various constructs

\begin{tabular}{lcccccccc}
\hline & 1 & 2 & 3 & 4 & 5 & 6 & 7 & 8 \\
\hline 1. Br_Equity & $\mathbf{0 . 8 4 2}$ & & & & & & & \\
2. Br_Satisfaction & 0.090 & $\mathbf{0 . 8 1 1}$ & & & & & & \\
3. Br_Love & 0.049 & 0.665 & $\mathbf{0 . 8 3 9}$ & & & & & \\
4. CEWB & 0.097 & 0.602 & 0.647 & $\mathbf{0 . 8 3 6}$ & & & & \\
5. Br-Loyalty & 0.510 & 0.241 & 0.179 & 0.193 & $\mathbf{0 . 7 8 8}$ & & & \\
6. Positive WOM & 0.492 & 0.190 & 0.180 & 0.166 & 0.686 & $\mathbf{0 . 8 8 1}$ & & \\
7. Price Premium & 0.424 & 0.222 & 0.164 & 0.209 & 0.759 & 0.581 & $\mathbf{0 . 8 5 9}$ & \\
8. Resist & 0.516 & 0.131 & 0.149 & 0.125 & 0.464 & 0.453 & 0.346 & $\mathbf{0 . 8 7 7}$ \\
\hline CR & $\mathbf{0 . 9 0 6}$ & $\mathbf{0 . 8 8 5}$ & $\mathbf{0 . 9 3 4}$ & $\mathbf{0 . 8 7 4}$ & $\mathbf{0 . 9 3 6}$ & $\mathbf{0 . 9 1 2}$ & $\mathbf{0 . 8 9 4}$ & $\mathbf{0 . 9 0 9}$ \\
ALPHA & $\mathbf{0 . 8 5 7}$ & $\mathbf{0 . 8 2 6}$ & $\mathbf{0 . 9 1 4}$ & $\mathbf{0 . 7 8 3}$ & $\mathbf{0 . 9 2 3}$ & $\mathbf{0 . 8 5 5}$ & $\mathbf{0 . 8 2 2}$ & $\mathbf{0 . 8 5 0}$ \\
\hline
\end{tabular}

Note: $\mathrm{CR}=$ composite reliability , correlations are under the diagonal, and Squared root AVEs are in the main diagonal

\section{Analysis and Results}

Results of PLS based structural equation modeling are reported in this section and for regression direct paths (see Table 5). $\mathrm{H}_{1}$ shows that as expected, satisfaction $(\beta=.646, p<.001)$ has positive significant effect on brand love. Whereas, contrary to our hypothesis $\mathrm{H}_{2}$ i.e. brand equity $(\beta=.042, n . s)$ has no significant effect on brand love; hence $\mathrm{H}_{2}$ was not supported. Brand love outcomes hypotheses such as brand loyalty $(\beta=.111, p<.05)$, positive WOM $(\beta=.128, p<.01)$, willingness to pay price premium $(\beta=.097, p<.05)$, and consumer resistance to negative information $(\beta=.099, p<.05)$, all have positive and significant effects, showing the acceptance of our hypotheses $\mathrm{H}_{3}-\mathrm{H}_{6}$. 


\subsection{Mediation Effects}

Zhao et al. (2010) by revisiting the pros and cons of most commonly used method to assess mediation effect (Baron and Kenny, 1986), proposed only to look for significance of indirect effects to establish mediation effect in comparison of fulfilling Baron and Kenny's three conditions. Our findings also proved that brand love significantly mediates the relationships between exogenous variable (brand satisfaction) and endogenous variables (brand loyalty, positive WOM, and willingness to pay price premium and consumer resistance to negative information). The indirect effects through brand love on outcome variables were not only significant but also enhanced the positive direct effects of satisfaction on brand loyalty, positive WOM and willingness to pay premium price as evident from total effects (see Table 6). Contrary to our hypotheses, however, the mediating effects of brand love between brand equity and outcome variables were not significant (see Table 6). Thus, all the direct and total effects are positive and significant. This implies that brand love is not a mediator between brand equity and outcome variables.

\subsection{Moderation Effects}

Customer expertise with brand was hypothesized to moderate the relationship between satisfaction and brand love, and similarly on the relationships of band love with the outcome variables (brand loyalty, positive WOM, willingness to pay price premium, and consumer resistance to negative information). The results (see Table 5) show that $\mathrm{H}_{9}$ was supported, the interaction coefficient was significant $(\beta=.170, p<.001)$.

Table 5: PLS-SEM Analysis Results

\begin{tabular}{|c|c|c|c|c|c|c|}
\hline \multicolumn{2}{|l|}{ Independent } & \multicolumn{5}{|c|}{ Dependent Variables (Path Coefficients i.e. Betas) } \\
\hline Variables & 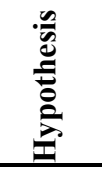 & 泀 & $\sum_{+}^{\sum}$ & 泀 & 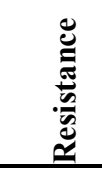 & 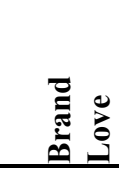 \\
\hline Gender & & -.026 & -.001 & -.038 & -.033 & \\
\hline Income & & -.042 & $-.076 \dagger$ & $-.082 *$ & .019 & \\
\hline Qualification & & $-.096^{*}$ & $-.100 *$ & $.067 \dagger$ & .009 & \\
\hline Brand Satisfaction & $\mathbf{H}_{1}$ & & & & & $.646^{* * *}$ \\
\hline Brand Equity & $\mathbf{H}_{2}$ & & & & & .042 \\
\hline Brand Love & $\mathbf{H}_{3}-\mathrm{H}_{6}$ & $.111^{*}$ & $.128 * *$ & $.097 *$ & $.099 *$ & \\
\hline \multicolumn{7}{|l|}{ Interaction/Moderating Effects: } \\
\hline - CEWB*Satisfaction & $\mathbf{H}_{9}$ & & & & & $.170 * * *$ \\
\hline - CEWB* Brand Love & $\mathbf{H}_{10 \mathbf{a}}$ & -.067 & & & & \\
\hline - CEWB* Brand Love & $\mathrm{H}_{10 \mathrm{~b}}$ & & .002 & & & \\
\hline - CEWB* Brand Love & $\mathbf{H}_{10 \mathrm{c}}$ & & & -.056 & & \\
\hline - CEWB* Brand Love & $\mathbf{H}_{10 \mathrm{~d}}$ & & & & $-.086^{*}$ & \\
\hline$R^{2}$ & & .353 & .312 & .265 & .324 & .386 \\
\hline Adjusted $R^{2}$ & & .343 & .302 & .254 & .312 & .381 \\
\hline
\end{tabular}

Note. $N=402$. Standardized coefficients (betas) are reported above along with $R^{2}$, Adjusted $R^{2}$.

Where: $* * * p<.001 ; * * p<.01 ; * p<.05$; whereas, $\dagger p<.10$

This implies that higher the expertise with brand, stronger will be the relationship between satisfaction and brand love. The moderating effect of consumers' expertise with their favorite brands on the relationship of brand love with the outcome variables was not significant for all the variables except consumer resistance to negative information. Interestingly the interaction coefficient was negative and significant $(\beta=-.086, p<.05)$. This implies that higher the expertise with brand, weaker will be the relationship between brand love and 
consumer resistance to negative information. The results of optimal model were presented (see Table 5) after deleting all the insignificant interaction effects from the model.

Table 6: Mediation Effects

\begin{tabular}{|c|c|c|c|c|}
\hline \multirow{2}{*}{\multicolumn{2}{|c|}{ Mediated Relationships }} & \multicolumn{3}{|c|}{ Effects } \\
\hline & & Direct & Indirect & Total \\
\hline Brand Satisfaction $\rightarrow$ Brand Love $\rightarrow$ Loyalty & $\mathrm{H}_{7 \mathrm{a}}$ & $.111^{*}$ & $.072 *$ & $.183 * * *$ \\
\hline Brand Satisfaction $\rightarrow$ Brand Love $\rightarrow+$ WOM & $\mathrm{H}_{7 \mathrm{~b}}$ & $.071 \dagger$ & $.083 * *$ & $.154 * * *$ \\
\hline Brand Satisfaction $\rightarrow$ Brand Love & $\mathrm{H}_{7 \mathrm{c}}$ & $.109 *$ & $.063 *$ & $.171 * * *$ \\
\hline Brand Satisfaction $\rightarrow$ Brand Love $\rightarrow$ Resistance & $\mathrm{H}_{7 \mathrm{~d}}$ & -.018 & $.064 *$ & .046 \\
\hline Brand Equity $\rightarrow$ Brand Love $\rightarrow$ Loyalty & $\mathrm{H}_{8 \mathrm{a}}$ & $.541 * * *$ & .005 & $.546 * * *$ \\
\hline Brand Equity $\rightarrow$ Brand Love $\rightarrow+$ WOM & $\mathrm{H}_{8 \mathrm{~b}}$ & $.490 * * *$ & .005 & $.495 * * *$ \\
\hline Brand Equity $\rightarrow$ Brand Love & $\mathrm{H}_{8 \mathrm{c}}$ & $.444 * * *$ & .004 & $.448 * * *$ \\
\hline Brand Equity $\rightarrow$ Brand Love $\rightarrow$ Resistance & $\mathrm{H}_{8 \mathrm{~d}}$ & $.545 * * *$ & .004 & $.549 * * *$ \\
\hline
\end{tabular}

Where: $* * * p<.001 ; * * p<.01 ; * p<.05 ;$ whereas, $\dagger p<.10$

\section{Discussion and Implications}

This study was conducted by realizing the importance and popularity of an emerging construct 'brand love' among practitioners and academics. When consumers start loving a brand the sales volume of that specific brand will automatically increase because brand love converts into brand loyalty over time and this leads to buy the same product repeatedly. Love emotion is a single, specific, and temporal emotion while love relationship is a long term and reliable relationship (Batra et al., 2012). This study has tried to observe brand love relationship in the form of its antecedents (satisfaction \& brand equity) and consequences (brand loyalty, positive WOM, willingness to pay price premium, and consumer resistance to negative information). We took the constructs that have already been studied independently in different studies, and our findings showed an integrated framework of brand love. By identifying relevant antecedents and consequences of brand-love marketing managers can focus on making strategies that create love in consumers for longer time relationship.

Our findings support the notion that customers' satisfaction is a strong predictor of brand love (Loureiro and Kaufmann, 2012). Brand equity, however, was not proven to be a significant predictor of brand love. Brand equity is a broad construct and has been studied in the literature with multiple dimensions such as perceived quality, brand awareness, image and association (Aaker, 1995; Keller, 1993). There are chances that different dimensions of brand equity may show different kind of relationship with brand love. Future studies may explore relationship of brand love and brand equity in all possible sub-constructs instead of an overall construct. Future studies may also explore brand love as an antecedent of brand equity.

The consequences of brand love are also important for the marketers. Our study empirically proved that brand loyalty, positive WOM, willingness to pay price premium, and resistance to negative information were the outcomes of strong brand love. Our findings are similar to Roy et al. (2013) that satisfied customers with strong love bond with brand show stronger brand loyalty as compared to those without love bonding. Our findings suggests that relationship between satisfaction and loyalty (Oliver, 1999) and with other outcome variables is not straightforward. Loyal customers are satisfied but not all satisfied customers are loyal or are ready to share positive WOM, and even not ready to pay price premium. Oliver (1999) worked on six possible relations, linking satisfaction and brand loyalty. He concluded that satisfaction is a transitioning stage in consumer behavior and over a period of time leads to loyalty. Our findings support this view as we can see that the total effect (sum of direct and indirect effects) enhanced while taking brand love as a mediator between satisfaction and loyalty.

Similarly, our results also prove that if a customer is emotionally attached with brand then it is quite possible that customer will be ready to pay price premium for that loved brand (Thomson et al., 2005). Our findings suggest that satisfied consumers are willing to invest their time and energy in spreading positive information about their loved brand (Bergkvist and Bech-Larsen, 2010). The higher indirect effect (see table 5) of satisfaction on positive WOM emphasize that people love to talk more about their loved brands as compared to brands with only 
satisfaction. Our results also support Bhattacharya and Sen's (2003) argument that connected consumers are more likely to stand with company at their difficult times. The mediating effect of brand love between satisfaction and resistance to negative information (see table 5) explains that satisfied customers rarely stand against negative information but customers with emotional bonding with company/brand are more likely to resist against negative information.

The moderating effect of consumer expertise with brand also plays a role in further strengthening the relationship between satisfaction and brand love. Past research found that cumulative satisfaction over a period of time leads to an emotional bonding between consumer and brand (Carroll and Ahuvia, 2006). On the other hand, moderating effects of consumer expertise on the relationships of brand love with outcome variables were not significant except for resistance to negative information. Interestingly, the effect was negative contrary to our prediction. It suggests further probing of underlying mechanism between brand love and resistance to negative information over time. Since this relationship is first of its kind to be explored in this study (as per researchers' knowledge) therefore, we may suggest that boredom emerging out of the use for a longer period of time could be a reason that a consumer feels, as he becomes an expert with a specific brand over time. Consequently, he stops resisting against negative information or shows willingness to know more about negative information about that brand.

Positive emotional connection and positive feelings are two different concepts. Positive feelings may exist for a short and specific time but positive emotional connection shows a strong bond and long run relationship between consumer and brand like an old school friend. Managers may achieve consumer-brand emotional connection by providing the brands with real spirit of attributes: such as a sense of quality from its origin, history, founder vision, corporate culture of the firm. It is important for a buyer to feel a sense of natural fit between himself and brand. Brands are created with immense efforts from producers to take place in the minds and hearts of consumers. In our study, most of the respondents mentioned iPhone as their loved brand and we believe that it is not a coincidence. There must be strong efforts behind it to develop such feelings for their brand and a great lesson to follow for marketing managers. People feel a strong connection with their loved brand and grow with them like old friends.

Managers always strive for increased investment from customers in the form of money, time, and energy for their brands. In this regard, the challenge for them is to convert the satisfied customer into a loyal one. Moreover, marketing managers with constraint budget, try to enhance their marketing return on investment. They should develop brand in such a way that it becomes consumers' desired identity and it must have the ability to express life deeper meanings and important values. Marketing managers should emphasize on intrinsic rewards/benefits for consumers, which is difficult to imitate and should try to improve them over time.

\section{Future directions and Conclusion}

No research is without limitations; our research also has some limitations that may provide opportunities for future research. Our findings and discussion suggests that more empirical and exploratory work is required to explore brand love construct itself, its antecedents and consequences. For instance, research work is required to identify the components of brand love and how these components interact with each other, especially to assess the role of attitude valence and attitude strength.

Brand love is based on interpersonal love theory. Literature tells that interpersonal love is of different kinds (e.g., parental, romantic, sexual etc.). Similarly, there may be different types of brand love that consumers feel for different brands, which should be explored in the future studies.

In our study, brand love was explored for smartphones in an eastern culture, future studies may explore other sectors of economic consumption such as cars, perfumes, and electronics brands. We used convenience-sampling technique to collect the data to test the model. Although our sample being a large one (402) was a good representative of population but convenience sampling has its own limitations. Future research could use other techniques to collect the data and compare findings. In addition, qualitative interviews method would be recommended to explore brand love in other eastern cultures to get the deeper meaning of Asian consumers.

We used customer expertise with brand as a moderator but the relationship was not significant for most of the outcome variables. Future studies may use other variables (such as experience and price) that may affect the relationship among brand love, antecedents, and consequences. We followed the approach used by Bagozzi et al (2016) in measuring brand love construct based on 56 items. Although, the measurement was satisfactory and validated but it's a complex method to measure brand love. Future studies may explore brand love scale based on 6-, 13- and 26-items proposed by Bagozzi et al. (2016), particularly in eastern settings. Comparative findings would be interesting to explore cultural effects on brand love dimensions. 
In conclusion, our study provides a basis for future studies on brand love, particularly in eastern settings. We conclude that emotional bonding is important between brands and consumers. In addition, satisfaction is not the ultimate outcome of branding efforts; it is a transitional stage that may lead to other important outcome variables that explain brands' strength.

Conflict of Interest Statement:

The corresponding author states that there is no conflict of interest.

\section{References}

Aaker, D.A. (1991), Managing Brand Equity: Capitalizing on the Value of a Brand Name, NY: Free Press.

Aaker, D.A. (1995), Strategic Market Management, New York: John Wiley \& Sons, Inc.

Aaker, D.A. (1996), Building Strong Brands, New York, Free Press.

Ahearne, M., Bhattacharya, C.B. and Gruen, T. (2005), “Antecedents and consequences of customer-company identification: expanding the role of relationship marketing”, The Journal of Applied Psychology, Vol. 90 No. 3, pp. 574-585.

Ahuvia, A. (2005), "Beyond the extended self: Loved objects and consumers' identity narratives", Journal of Consumer Research, Vol. 32 No. 1, pp. 171-184.

Ahuvia, A., Bagozzi, R. and Batra, R. (2013), "Psychometric vs. C-OAR-SE measures of brand love: A reply to Rossiter", Marketing Letters, Vol. 25, available at:https://doi.org/10.1007/s11002-013-9251-4.

Ailawadi, K.L., Lehmann, D.R. and Neslin, S.A. (2003), "Revenue Premium as an Outcome Measure of Brand Equity”, Journal of Marketing, Vol. 67 No. 4, pp. 1-17.

Albert, N., Merunka, D. and Valette-Florence, P. (2008), "When consumers love their brands: Exploring the concept and its dimensions", Journal of Business Research, Vol. 61 No. 10, pp. 1062-1075.

AMA. (1960), Marketing Definitions: A Glossary of Marketing Terms, American Marketing Association, Chicago, II.

Anselmsson, J., Bondesson, N.V. and Johansson, U. (2014), “Brand image and customers' willingness to pay a price premium for food brands", Journal of Product \& Brand Management, Vol. 23 No. 2, pp. 90-102.

Argyle, M. and Henderson, M. (1984), “The Rules of Friendship”, Journal of Social and Personal Relationships, Vol. 1 No. 2, pp. 211-237.

Bagozzi, R.P., Batra, R. and Ahuvia, A. (2016), "Brand love: development and validation of a practical scale”, Marketing Letters, pp. 1-14.

Baron, R.M. and Kenny, D.A. (1986), “The moderator-mediator variable distinction in social psychological research: conceptual, strategic, and statistical considerations", Journal of Personality and Social Psychology, Vol. 51 No. 6, pp. 1173-1182.

Batra, R., Ahuvia, A. and Bagozzi, R.P. (2012), "Brand love”, Journal of Marketing, Vol. 76 No. 2, pp. 1-16.

Bergkvist, L. and Bech-Larsen, T. (2010), "Two studies of consequences and actionable antecedents of brand love", Journal of Brand Management, Vol. 17 No. 7, pp. 504-518.

Bhattacharya, C.B. and Sen, S. (2003), "Consumer-Company Identification: A Framework for Understanding Consumers' Relationships with Companies”, Journal of Marketing, Vol. 67 No. 2, pp. 76-88.

Brakus, J.J., Schmitt, B.H. and Zarantonello, L. (2009), "Brand Experience: What Is It? How Is It Measured? Does It Affect Loyalty?”, Journal of Marketing, Vol. 73 No. 3, pp. 52-68.

Carroll, B.A. and Ahuvia, A. (2006), "Some antecedents and outcomes of brand love", Marketing Letters, Vol. 17 No. 2, pp. 79-89.

Chaudhuri, A. and Holbrook, M.B. (2001), "The Chain of Effects from Brand Trust and Brand Affect to Brand Performance: The Role of Brand Loyalty”, Journal of Marketing, Vol. 65 No. 2, pp. 81-93. 
Day, G.S. (1971), “Attitude change, media and word of mouth”, Journal of Advertising Research, Vol. 11 No. 6 , pp. 31-40.

Doyle, P. (2001), "Shareholder-value-based brand strategies", Journal of Brand Management, Vol. 9 No. 1, pp. $20-30$.

Eckhardt, G.M. and Dholakia, N. (2013), “Addressing the mega imbalance: interpretive exploration of Asia”, Qualitative Market Research: An International Journal, Vol. 16 No. 1, pp. 4-11.

Eisingerich, A.B., Rubera, G., Seifert, M. and Bhardwaj, G. (2011), "Doing Good and Doing Better despite Negative Information?: The Role of Corporate Social Responsibility in Consumer Resistance to Negative Information", Journal of Service Research, Vol. 14 No. 1, pp. 60-75.

Escalas, J.E. (1997), "Meaningful self-brand connections and consumer product experience stories”, Advances in Consumer Research, Vol. 24, p. 309.

Fornell, C. and Larcker, D.F. (1981), "Evaluating Structural Equation Models with Unobservable Variables and Measurement Error", Journal of Marketing Research, Vol. 18 No. 1, pp. 39-50.

Fournier, S. (1998), "Consumers and Their Brands: Developing Relationship Theory in Consumer Research", Journal of Consumer Research, Vol. 24 No. 4, pp. 343-353.

Fournier, S. and Mick, D.G. (1999), "Rediscovering Satisfaction”, The Journal of Marketing, Vol. 63 No. 4, pp. $5-23$.

Guo, L. and Meng, X. (2008), “Consumer knowledge and its consequences: an international comparison”, International Journal of Consumer Studies, Vol. 32 No. 3, pp. 260-268.

Ha, H.-Y., Janda, S. and Muthaly, S. (2010), "Development of brand equity: evaluation of four alternative models", The Service Industries Journal, Vol. 30 No. 6, pp. 911-928.

Hair, J.F.Jr., Anderson, R.E., Tatham, R.L. and Black, W.C. (2009), Multivariate Data Analysis, 7th Ed., New Jersey: Prentice-Hall.

Hayes, A.F. (2013), Introduction to Mediation, Moderation, and Conditional Process Analysis: A RegressionBased Approach, New York: Guilford Press, available at: https:/www.guilford.com/books/Introduction-to-Mediation-Moderation-and-Conditional-ProcessAnalysis/Andrew-Hayes/9781609182304 (accessed 31 May 2017).

Hendrick, S.S. and Hendrick, C. (2006), "Measuring respect in close relationships", Journal of Social and Personal Relationships, Vol. 23, pp. 881-899.

Keller, K.L. (1993), “Conceptualizing, Measuring, and Managing Customer-Based Brand Equity”, The Journal of Marketing, Vol. 57 No. 1, pp. 1-22.

Keller, K.L. (2003), “Brand Synthesis: The Multidimensionality of Brand Knowledge”, Journal of Consumer Research: An Interdisciplinary Quarterly, Vol. 29 No. 4, pp. 595-600.

Kock, N. (2015), “WarpPLS 5.0 User Manual - Collaborative for International”, ScriptWarp Systems, Laredo, TX.

Loureiro, S.M.C. and Kaufmann, H.R. (2012), "Explaining Love of Wine Brands”, Journal of Promotion Management, Vol. 18 No. 3, pp. 329-343.

Marin, L., Ruiz, S. and Rubio, A. (2009), "The Role of Identity Salience in the Effects of Corporate Social Responsibility on Consumer Behavior", Journal of Business Ethics, Vol. 84 No. 1, pp. 65-78.

Mason, K. and Bequette, J. (1998), "Product experience and consumer product attribute inference accuracy", Journal of Consumer Marketing, Vol. 15 No. 4, pp. 343-357.

Oliver, R.L. (1999), “Whence Consumer Loyalty?”, The Journal of Marketing, Vol. 63, pp. 33-44.

Park, C.W., MacInnis, D.J., Priester, J., Eisingerich, A.B. and Iacobucci, D. (2010), "Brand Attachment and Brand Attitude Strength: Conceptual and Empirical Differentiation of Two Critical Brand Equity Drivers", Journal of Marketing, Vol. 74 No. 6, pp. 1-17. 
Rauschnabel, P.A. and Ahuvia, A. (2014), "You're so lovable: Anthropomorphism and brand love", Journal of Brand Management, Vol. 21 No. 5, pp. 372-395.

Rossiter, J.R. (2012), “A new C-OAR-SE-based content-valid and predictively valid measure that distinguishes brand love from brand liking”, Marketing Letters, Vol. 23 No. 3, pp. 905-916.

Roy, S.K., Eshghi, A. and Sarkar, A. (2013), “Antecedents and consequences of brand love”, Journal of Brand Management, Vol. 20 No. 4, pp. 325-332.

Rubin, Z. (1970), "Measurement of romantic love”, Journal of Personality and Social Psychology, Vol. 16 No. 2, pp. 265-273.

Sethuraman, R. (2001), What Makes Consumers Pay More for National Brands than for Store Brands - Image or Quality?, SSRN Scholarly Paper No. ID 310883, Social Science Research Network, Rochester, NY, available at: https://papers.ssrn.com/abstract=310883 (accessed 10 August 2017).

Sheth, J.N. (1971), "Word-of-Mouth Low-Risk Innovations”, Journal of Advertising Research, Vol. 11, pp. 1518.

Shimp, T.A. and Madden, T.J. (1988), “Consumer-Object Relations: a Conceptual Framework Based Analogously on Sternberg's Triangular Theory of Love”, ACR North American Advances, Vol. NA-15, pp. 163-168ahlu.

Sternberg, R.J. (1986), “A triangular theory of love”, Psychological Review, Vol. 93 No. 2, pp. 119-135.

Tabachnick, B.G. and Fidell, L.S. (2013), Using Multivariate Statistics, 6th Edition, Boston: Pearson International Edition.

Thomson, M., MacInnis, D.J. and Whan Park, C. (2005), "The Ties That Bind: Measuring the Strength of Consumers' Emotional Attachments to Brands”, Journal of Consumer Psychology, Vol. 15 No. 1, pp. $77-91$.

Tuominen, P. (1999), "Managing Brand Equity”, Liiketaloudellinen Aikakauskirja: The Finish Journal of Business, Vol. 48 No. 1, pp. 65-100.

Westbrook, R.A. (1987), "Product/Consumption-Based Affective Responses and Postpurchase Processes", Journal of Marketing Research, Vol. 24 No. 3, pp. 258-270.

Wetzels, M., Odekerken-Schröder, G. and van Oppen, C. (2009), "Using PLS Path Modeling for Assessing Hierarchical Construct Models: Guidelines and Empirical Illustration”, MIS Quarterly, Vol. 33 No. 1, pp. 177-195.

Zeithaml, V.A., Berry, L.L. and Parasuraman, A. (1996), “The Behavioral Consequences of Service Quality”, Journal of Marketing, Vol. 60 No. 2, pp. 31-46.

Zhao, X., Jr, J.G.L. and Chen, Q. (2010), "Reconsidering Baron and Kenny: Myths and Truths About Mediation Analysis", Journal of Consumer Research, Vol. 37, pp. 197-206. 